\title{
BIBLIOGRAPHY
}

The following list of publications has been compiled from the March, Apri1, and May 1965 GEOSCIENCE ABSTRACTS (published by the American Geological Institute):

Area 1 and Regional Geology

BERGIN, M.J., 1964, Bedrock geology of the Penn Yan and Keuka Park Quadrangles, New York: U.S. Geol. Survey, Bu11. 1161-G, 35 p.

BOUCOT, A.J., and others, 1964, Reconnaissance bedrock geology of the Presque Isle Quadrangle, Maine: Maine Geol. Survey, Quad. Mapping Ser. No. 2, 123 p.

BUEHLER, E.J., and TESMER, I.H., 1964, Geology of Erie County, New York: Buffalo Soc. Nat. Sci., Bul1., v. 21, no. 3, 118 p.

DENNIS, J.G., 1964, The geology of the Enosburg Area, Vermont: Vermont, Geol. Survey, Bu11. No. 23, 56 p.

DE WITT, W., Jr., and COLTON, G.W., 1964, Bedrock geology of the Evitts Creek and Pattersons Creek Quadrangles, Maryland, Pennsylvania, and West Virgina: U.S. Geol. Survey, Bu11. 1173, $90 \mathrm{p}$.

GADD, N.R., 1964, Surficial geology, Beauceville Map-Area, Quebec: Canada, Geol. Survey, Paper 64-12, 3 p.

JOHNSON, H.S., Jr., 1964, Geology in South Carolina: South Carolina, State Devel. Board, Div. Geology, Misc. Rept. 3, 11 p.

KONIG, R.H., and DENNIS, J.G., 1964, The geology of the Harwick Area, Vermont: Vermont, Geol. Survey, Bull. No. 24, 57 p.

TREVES, S.B., and BOELLSTORFF, J., 1965, General geology of a portion of the Tasersiaq Area, Southwest Greenland: Compass, v. 42, no. 2, p. $116-121$

Geomorphology

BLAKE, W., Jr., 1964, Preliminary account of the glacial history of Bathurst Island, Arctic Archipelago: Canada, Geol. Survey, Paper 64-30, 8 p.

GADD, N.R., 1964, Moraines in the Appalachian Region of Quebec: Geol. Soc. America, Bu11., v. 75, no. 12, p. 1249-1254 
GRIBBON, P.W.F., 1964, Recession of glacier Tasissarssik A., East Greenland: Jour. Glaciology, v. 5, no. 39, p. 361-363

LILLY, H.D., 1965, Submarine examination of the Virgin Rocks Area, Grand Banks, Newfoundland: Preliminary Note: Geol. Soc. America, Bul1., v. 76 , no. 1, p. 131

WILDING, L.P., and others, 1964, Morley and Blount soils: A statistical summary of certain physical and chemical properties of some selected profiles from Ohio: Soil Sci. Soc. America, Proc., v. 28, no. 5, p. 674-679

\section{Structura1 Geology}

ENGELEN, G.B., 1964, A hypothesis on the origin of the Bermuda Rise. With Appendix, by R.W. van Bemmelen: Tectonophysics, v. 1, no. 1, p. $85-96$

FYSON, W.K., 1964, Repeated trends of folds and cross-folds in palaeozoic rocks, Parrsboro, Nova Scotia: Can. Jour. Earth Sci., v. 1, no. 3, p. 167-183

McLAUGHLIN, D.B., 1963, Newly recognized folding in the Triassic of Pennsylvania: Pennsylvania Acad. Sci., Proc., v. 37, p. 156-159

OSBERG, P.H., 1965, Structural geology of the Knowlton-Richmond Area, Quebec: Geol. Soc. America, Bul1., v. 76, no. 2, p. 223-250

REED, J.C., and BYRANT, B.H., 1964, Evidence for strike-slip faulting along the Brevard Zone in North Carolina: Geol. Soc. America, Bull., v. 75 , no. 12 , p. 1177-1195

\section{Stratigraphy and Historica1 Geology}

BROOKINS, D.G., and HURLEY, P.M., 1965, Rb-Sr geochronologica1 investigations in the Middle Haddam and Glastonbury quadrangles, Eastern Connecticut: Am. Jour. Sci., v. 263, no. 1, p. 1-16

CALVERT, W.L., 1964, Sub-trenton rocks from Fayette County, Ohio, to Brant County, Ontario: Ohio, Div. Geol. Survey, Rept. Inv. No. 52, 7 p.

CHRISTIE, R.L., 1964, Diabase-gabbro sil1s and related rocks of Banks and Victoria Islands, Arctic Archipelago: Canada, Geol. Survey, Bul1. 105, $13 \mathrm{p}$. 
CORMIER, R.F., and KELLY, A.M., 1964, Absolute age of the Fisset Brook formation and the Devonian-Mississippian boundary, Cape Breton Island, Nova Scotia: Can. Jour. Earth Sci., v. 1, no. 3, p. $159-166$

DONOVAN, D.T., 1964, Stratigraphy and anmonite fauna of the volgian and berriasian rocks of East Greenland: Meddele1ser on Gr $\phi$ nland, v. 154 , no. 4,34 p.

DRAKE, A.A., Jr., 1965, Carbonate rocks of Cambrian and Ordovician Age, Northampton and Bucks Counties, eastern Pennsylvania, and Warren and Hunterdon Counties, western New Jersey: U.S. Geol. Survey, Bul1. 1194-L, 7 p.

FRAREY, M.J., and DUFFELL, S., 1964, Revised stratigraphic nomenclature for the central part of the Labrador Trough: Canada, Geol. Survey, Paper 64-25, 13 p.

GLAESER, J.D., 1964, Lithostratigraphic nomenclature of the Triassic Newark-Gettysburg Basin: Pennsylvania Acad. Sci., Proc., v. 37, p. $179-188$

HOSKINS, D.M., 1964, A provisional Silurian to Mississippian rockstratigraphic column for central Pennsylvania: Pennsylvania Acad. Sic., Proc., v. 37, p. 199-205

KAY, M., and COLBERT, E.H., 1965, Stratigraphy and life history: $736 \mathrm{p}$.

NAYLOR, R.S., and BOUCOT, A.J., 1965, Origin and distribution of rocks of Ludlow age (Late Silurian) in the northern Appalachians: Am. Jour. Sci., v. 263, no. 2 ,

RANKIN, D.W., 1965, The Matagamon Sandstone - a new Devonian formation in North-central Maine: U.S. Geo1. Survey, Bu11. 1194-F, 9 p.

REED, J.C., 1964, A new study of Tertiary and Cretaceous sediments from the 2306-foot 1901 Atlantic City, New Jersey, We11: Pennsylvania Acad. Sci., Proc., v. 37, p. 189-198

SCOTFORD, D.M., 1965, Petrology of the Cincinnatian series shales and environmental implications: Geol. Soc. America, Bull., v. 76, no. 2, p. 193-222

ULTEIG, J.R., 1964, Upper Niagaran and Cayugan stratigraphy of northeastern Ohio and adjacent areas: Ohio, Div. Geol. Survey, Rept. Inv. No. $51,48 \mathrm{p}$.

WINDER, C.G., 1964, Ottawa should be a middle Ordovician group: Am. Assoc. Petroleum Geologists, Bu11., v. 48, no. 10, p. 1730-1732 


\section{$\underline{\text { Paleontology }}$}

BARNETT, S.G., 1965, 3d. Conodonts of the Jacksonburg limestone (middle ordovician) of northwestern New Jersey and eastern Pennsylvania: Micropaleontology, v. 11, no. 1, p. 59-80

CARROLL, R.L., 1963, A microsaur from the Pennsylvanian of Joggins, Nova Scotia: Canada, Nat1. Mus., Nat. History Papers, no. 22, $13 \mathrm{p}$.

HOPSON, J.A., 1964, Pseudodontornis and other large marine birds from the Miocene to South Carolina: Yale Univ., Peabody Mus. Nat. History, Postilla, no. 83, 19 p.

HUELSENBECK, P., and BEERBOWER, J.R., 1963, Paleoecology of upper Cretaceous (Navesink) beds at Poricy Brook, Monmouth County, New Jersey: Pennsylvania Acad. Sci., Proc., v. 37, p. 175-178

MERRILL, A.S., and others, 1965, Ancient Oyster shells on the Atlantic Continental Shelf: Science, v. 147, no. 3656, p. 398-400

RADER, E.K., 1965, First discovery of the Hollinacean Ostracoda Pseudorakvere1la from the United States (Trenton Member, Martinsburg formation, Virgina): Jour. Paleontology, v. 39, no. 1, p. 159161

RICHARDS, H.G., and WERNER, E., 1964, Invertebrate fossils from cores from the Continental Shelf off New Jersey: Acad. Nat. Sci. Philadelphia, Notulae Naturae, no. 372, 7 p.

VILKS, G., 1964, Foraminiferal study of East Bay, Mackenzie King Island, district of Franklin (Polar Continental Shelf Project): Canada, Geo1. Survey, Paper 64-53, 26 p.

ZENGER, D.H., 1965, Occurrence of the pelecypod Paracyclas in the upper Devonian of New York State: Jour. Paleontology, v. 39, no. 1, p. $153-155$

\section{Geophysics}

CLAY, C.S., and RONA, P.A., 1965, Studies of seismic reflections from thin layers on the ocean bottom in the western North Atlantic: Jour. Geophys. Research, v. 70, no. 4, p. 855-869

EDGERTON, H.E., and others, 1964, Sonar probing in Narragansett Bay: Science, v. 146, no. 3650 , p. 1459-1460

GOODACRE, A.K., 1964, A shipborne gravimeter testing range near Halifax, Nova Scotia: Jour. Geophys. Research, v. 69, no. 24, p. $5373-5381$

HELSLEY, C.E., 1965, Paleomagnetic results from the lower Permian Dunkard series of West Virgina: Jour. Geophys. Research, v. 70, no. 2, p. 413-424 
IRVING, E., and OPDYKE, N.D., 1965, The palaeomagnetism of the Bloomsburg red beds and its possible application to the tectonic history of the Appalachians: Royal Astron. Soc., Geophys. Jour., v. 9, no. $2 / 3$, p.' $153-167$

IVANOV, M.M., 1963, Depth of sources of secular magnetic field variations in the oceans: Geomagnetism \& Aeronomy, in translation, v. 3, no. 1 , p. $113-116$

LePICHON, XAVIER, and others, 1965, Crustal structure of the midocean ridges. 1. Seismic refraction measurements: Jour. Geophys. Research, v. 70, no. 2, p. 319-339

ROY, J.L., 1963, Palaeomagnetism of Prince Edward Island: Ottawa, Dominion Observatory, Contr., v. 5, no. 23, 6 p.

SANDER, G.W. and OVERTON, A., 1965, Deep seismic refraction investigation in the Canadian Arctic Archipelago: Geophysics, v. 30, no. 1, p. $87-96$

TALWANI, MANIK, and others, 1965, Crustal structure of the mid-ocean ridges. 2. Computed model from gravity and seismic refraction data: Jour. Geophys. Research, v. 70 , no. 2, p. 341-352

ISACKS, BRYAN, and OLIVER, J.E., 1964, Seismic waves with frequences from 1 to 100 cycles per second recorded in a deep mine in northern New Jersey: Seismol. Soc. America, Bul1., v. 54, no. 6, p. 1941-1979

WHITHAM, K., 1964, Anomalies in geomagnetic variations in the Arctic Archipelago of Canada: Ottawa, Dominion Observatory, Contr., v. 5, no. $28,14 \mathrm{p}$.

\section{$\underline{\text { Sedimentary Petrology }}$}

BUCHWALD, C.E., 1965, Primary origin of the Fiddlers Green Dolomite (Upper Silurian, New York): Compass, v. 42, no. 3, p. 164-179

CROSS, C.I., 1964, The Parramore Island mounds of Virgina: Geog. Rev., v. 54, no. 4, p. 502-515

DUANE, D.B., 1964, Significance of skewness in recent sediments, western Pamlico Sound, North Carolina: Jour. Sed. Petrology, v. 34 , no. 4, P. $864-874$

HARRISON, WYMAN, and others, 1964, Sediments of lower Chesapeake Bay, with emphasis on mass properties: Jour. Sed. Petrology, v. 34, no. 4 , p. $727-755$ 
KRINSLEY, D.H., and others, 1964, Transportation of sand grains along the Atlantic shore of Long Tsland, New York: An application of electron microscopy: Marine Geology, v. 2, no. 1/2, p. 100-120

MAYO, C.R., 1965, Petrography of a middle Devonian bioherm, southwestern Ontario, Canada: Compass, v. 42, no. 2, p. 88-100

MCBRIDE, E.F., 1964, Review of turbidite studies in the United States (In: Bouma, Arnold H., and A. Brouwer, eds. Turbidites: p. 93-105

PILKEY, O.H., 1964, The size distribution and mineralogy of the carbonate fraction of United States South Atlantic Shelf and upper slope sediments: Marine Geology, v. 2, no. 1/2, p. 121-136

Geohydrology

CUSHMAN, R.V,, and others, 1964, Records and logs of selected wells and test borings and chemical analyses of water in north-central

Connecticut: Connecticut, Water Resources Comm., Connecticut Water Resources Bull. No. 4, 27 p.

FREEZE, R.A., 1964, Groundwater resources of the Lachine-Saint-Jean area, Quebec (South of St. Lawrence River), (Sheets) $31 \mathrm{H} / 5$ (Part of) and $31 \mathrm{H} / 6 \mathrm{~W} \mathrm{1/2:} \mathrm{Canada,} \mathrm{Geol.} \mathrm{Survey,} \mathrm{Bul1.} \mathrm{112,}$ $19 \mathrm{p}$.

JOHNSTON, R.H., 1964, Ground water in the Niagara Falls area, New York; with emphasis on the water-bearing characteristics of the bedrock: New York (State), Water Resources Comm., Bul1. GW-53, $93 \mathrm{p}$.

RANDALL, A.D., 1964, Records and logs of selected we11s and test borings, records of springs, and chemical analyses of water in the Farmington-Granby area, Connecticut: Connecticut, Water Resources Comm., Connecticut Water Resources Bull. No. 3, 25 p.

ROBISON, T.M., 1964, Occurrence and availability of gound water in Ohio County, West Virgina: West Virgina Veol. Survey, Bu11. 27, $57 \mathrm{p}$.

\section{Mineralogy}

JAMBOR, J.L., and BOYLE, R.W., 1965, Moorhousette and aplowite, new cobalt minerals from Walton, Nova Scotia: Can. Mineralogist, v.8, pt. 2, p. 166-171 
SCHOEN, R., 1964, Clay minerals of the Silurian Clinton Ironstones, New York State: Jour. Sed. Petrology, v. 34, no. 4, p. 855-863

\section{Mineral Deposits}

BURGESS, R.J., 1963, New strikes spark Cambrian play in Ohio, South Ontario: 0il \& Gas Jour., v. 61, no. 9, p. 180-183

BURGESS, R.J., 1963, Ohio, southern Ontario areas on threshold of big Cambrian play: 0i1 \& Gas Jour., v. 61, no. 10, p. 128-131

GUILLET, G.R., 1964, Clay and shale in Ontario. A review: Ontario, Dept. Mines, Prelim. Rept. P.R., 26 p.

HEWITT, D.F., 1964, Preliminary report on physical properties of Ontario terrazzo aggregates: Ontario, Dept. Mines, Prelim, Rept. $34 \mathrm{p}$.

POUNDER, J.A., 1963, Structure economics play key roles in Guelph-Lockport search: 0 il \& Gas Jour., v. 61, no. 6, p. 162-164

SITLER, G.G., Jr., 1963, Cambrian rocks are target no. 1 in eastern Ohio's vigorous oil search: 0il \& Gas Jour., v. 61, no. 20, p. $198-205$ 